\title{
School Financial Governance Practice
}

\author{
Sri Rahayu ${ }^{1}$, Yudi $^{2}$, Rahayu $^{3}$ \\ \{sri_rahayu@unja.ac.id ${ }^{1}$,yudi.telanai@gmail.com², rahayu-fe@unja.ac.id ${ }^{3}$ \} \\ Accounting Department, Universitas Jambi \\ Jalan Raya Jambi Muaro Bulian km. 15, Mendalo Darat, 36361, Jambi, Indonesia ${ }^{1,2,3}$
}

\begin{abstract}
This study aims to describe the practice of school financial governance. Three elements of financial governance are participation, accountability, and transparency. Qualitative data analysis was used to analyze the data of this study. Questionnaires, interviews collected data, and focus group discussions. The participants were teachers, employees and principals of elementary and junior high schools in Jambi City. The results of the study found that school financial management was good. The highest application is on the element of accountability, while the lowest application is on transparency. The causes of the not yet optimal school financial management understanding of parents and the community still need to be improved. Human resources in schools are still limited. In addition, the role of school supervisors also needs to be increased to play an active role in academics and oversee financial aspects.
\end{abstract}

Keywords: Schools; Financial Governance; Participation; Accountability; Transparency

\section{Introduction}

Good financial governance is essential to realize a clean government [1]. Community demands for achieving clean government are increasing for all government organizations, including schools. Since schools in Indonesia are required to implement School-Based Management (SBM) and receive an allocation of school operational funds, schools must also apply the principles of good governance. Theoretical ideas of participation, decentralization, the delegation of authority, and competition are at the root of the principles of SBM [2]. Schools independently manage their finances, so they are no longer just the organizers of academic activities.

School operational assistance funds allocated from 2005 became the main trigger for SBM implementation in Indonesia [3]. An essential feature of SBM in schools is the decentralization of budgets at the school level. Schools have broader financial management autonomy. Although relatively new to schools at the time, schools had to undergo financial management. The principal becomes the manager who is responsible for managing school finances. Good governance is a set of responsibilities, practices, policies, and procedures implemented by an institution to provide strategic direction to ensure that the goals are achieved, and resources are used responsibly. Schools need support to practice good governance from stakeholders, and ultimately it is hoped that quality education can be realized. Therefore, good governance is essential for schools, including in the financial sector. 
Schools with greater autonomy and can work with their stakeholders will be successful [4]. Therefore, schools are required to implement good financial governance. The implementation of good financial governance will provide opportunities for the participation of all key stakeholders. It can ensure that the use of funds is appropriate for students and the community, increase efficiency and effectiveness of fund management, improve school performance and increase parental and public trust in schools [5]. Good governance in the education system will result in the effective provision of educational services [6]. The basic dimensions/principles of school governance are participation, accountability, transparency, and integrity [5]. Integrity can be demonstrated by the implementation of good internal control in the organization concerned.

Accounting research in Indonesia has not focused much on school financial management. Research in educational institutions is still mostly carried out by researchers in education who look at academic aspects such as curriculum and learning processes. Financial management is also an important aspect of achieving quality education. Quality education, especially basic education, is very important. Basic education is mandatory for all Indonesian citizens enrolled in Elementary School/Madrasah Ibtida'yah Institutions and Junior High School/Madrasah Tsanawiyah institutions. The quality of basic education is very important to note because it is the door to the younger generation's future [7]. Education will provide new skills, improve the quality of life, and make it easier for someone to earn an income [8], [9]. This study aims to reveal the practice of good financial governance in schools. The results of this study can contribute to the government in formulating school financial management policies. In addition, this study's results are also expected to enrich the application of the theory of good financial governance in government organizations, especially for schools that accounting researchers in Indonesia have not widely studied.

\section{Literature Review}

Agency problems can be found in the relationship between agents and principals in the company [10]. Agents are parties who carry out their duties as mandated by the owners of capital. The agent is the company's management. The principal is the party who gives the trust, entrusts the capital to be run by the agent. Problems in the relationship between the two arise because of the information asymmetry between the two parties. Agents have wider access to information on company activities because they directly manage company operations. Due to opportunistic behavior, agents often take advantage of this access to information to benefit themselves or certain groups. This attitude, of course, can harm the principal. Agency relationships in government organizations, both at the local government level and regional apparatus [11]. Agency relations in government organizations are broader in scope than private ones. Government organizations become agents in their relationship with the community, the DPR or DPRD as representatives of the community and higher organizations.

Schools as a government organization can also be seen as agents in this agency relationship. Schools carry out the mandate to manage educational activities and education funds from principals. Principal schools are the government (central and local), parents, school committees, education offices, and the community. In this agency relationship, it can be a problem if the school management, in this case, is led by the principal, being opportunistic as well as company management. One solution is the implementation of Good financial governance. 
Government organizations such as schools are also required to implement good governance. Schools must implement good governance as a consequence of implementing SBM. SBM provides management autonomy to schools from an operational and financial perspective [12]. In implementing SBM, cooperation between schools and all stakeholders is needed to determine the school's programs and activities.

Some of the benefits for schools that implement good financial governance, according to [5], include:

a. Increasing the trust of parents and the community in schools.

b. Improving the efficiency and effectiveness of school management.

c. Able to improve school administrative performance, then can continue to encourage the development of school performance.

d. Ensure that funds are used for the benefit of students and the community.

e. Increase participation of all key stakeholders.

The four basic principles of good financial governance are accountability, transparency, participation, and integrity [5]. This study uses three main principles of governance, namely accountability, transparency, and participation. Integrity is not used because it is assumed to be related to internal control. The manifestation of accountability in Indonesia is the issuance of Law no. 17 of 2003 concerning State Finance. School accountability is the school's obligation to provide responsibility for the entire organization and implement the mission and functions of education. The implementation of good accountability will be able to improve the image of the educational organization concerned. In addition, it will also be able to improve the quality and quality of schools [13].

Transparency is the openness of access to information for the public to the required information. School transparency means the accessibility of stakeholders to all information on the management and implementation of education, both from the academic and management aspects, including finance. Technical Instructions Accountability for the use of school operational funds already requires schools to carry out financial management transparently. This is evidenced by the opening of access to the School Budget Activity Plan (RKAS) and accountability reports for the use of school operational funds for parents, students, and committees. The financial management of BOS funds is technically regulated in a Decree of the Minister of Education and Culture. For example, Permendikbud No. 06 of 2021 concerning Technical Guidelines for Regular School Operational Assistance Funds Management. Transparency will increase the participation of school stakeholders.

Participation is also expected to continue to be increased by schools. For example, in managing BOS funds, schools must involve committees and parents to take an active role in determining programs and activities to be run by the school. Schools with a high level of parental participation will improve the quality of school activities and operations. This, of course, has an impact on the quality of the learning process. Two aspects of the principle of public policy transparency are public communication by the government and the right of the community to access information. These two aspects also influence the transparency of public policies. Both will be very difficult to do if the government does not handle its performance properly. Public communication demands government efforts to open and disseminate relevant information and activities. Transparency must be balanced, also with the need for institutional confidentiality and information that affects individual privacy rights. 


\section{Research Method}

Researchers explore the practice of good financial governance with qualitative research. Quantitative methods are still the mainstream for economic research in general and accounting in particular. However, the use of qualitative methods has begun to be widely used. The qualitative method has the advantage of revealing more deeply because the researcher directly interacts with the participants. Qualitative methods do not aim to generalize research results but can reveal the actual practices of participants in the field. This research was conducted with public elementary school and junior high school educational service institutions in Jambi City. The object of this research is the practice of good financial governance at the two levels of education. Data from the Jambi City Education Office shows 187 State Elementary Schools and 25 State Junior High Schools in Jambi City. The public elementary school and junior high school are spread over six regional coordinators under the coordination of the Jambi City Education Office.

Researchers set a sample size of 139 schools using the Yamane formula [14]. Furthermore, to determine the sample per region, the used cluster sampling method was. Cluster sampling is done by dividing the population into several subgroups [15]. The most popular type of cluster sample used is the area sample. Furthermore, the determination of the schools that will be used as samples is chosen randomly. Respondents are principals who act as managers of school financial management. Questionnaires that were returned and processed amounted to 115 from 95 elementary school respondents and 10 junior high school respondents. Primary data and secondary data are used in this study. Sources of data came from schools and the Jambi City Education Office. The survey method with a questionnaire related to the practice of good financial governance. While the secondary data required comes from documents and policies relevant to the topic of study. Data mining was carried out using in-depth interviews and focus group discussions (FGD). These data were obtained from each school and related agencies such as the Jambi City Education Office.

Questionnaire data to measure the level of practice using the average respondents' answers. The assessment is divided into five groups: group 1 for the average respondent's answer between 1-1.99, including the very bad category. Group 2 for the average respondent's answer between 2-2.99 is in a bad category. Group 3 for the average respondent's answer between 33.99 is in the fairly good category. group 4 for the average respondent's answer between 44.99 is in a good category. group 5 for the average respondent's answer between 5 is in the very good category. Qualitative data analysis was carried out through the following stages: 1) Performing data filtering; 2) set a theme; 3) determine the relationship between themes; and 4) determine conclusions [16]. The validity of the qualitative data was tested by using triangulation of methods and sources. Triangulation is the easiest way of testing qualitative data [17].

The variables in this study are good financial governance (GSG), internal control system, and education service performance. Good financial governance practices can be seen with implementing governance principles based on the principles of implementing School-Based Management (SBM). The SBM principle adopted refers to the Technical Guidelines for School Fund Management established by the Ministry of Education and Culture. The essence of implementing SBM is transparency, accountability, and participation [12]. The researcher used a questionnaire with twenty-one questions with the implementation of Good financial Governance. From the questionnaire answer, it can be seen that the level of application, namely the frequency of activity. The frequency scale asks respondents to rate how often or how many times something has or will happen. The answer choices can range from never 
(score 1) to always (score 5). Frequency answer choices measure a personality scale in which respondents are asked to indicate how often they perform certain behaviors.

\section{Result and Discussion}

\subsection{Why is It Important for Schools to Implement Good Financial Governance?}

Schools cannot avoid implementing a good financial government because the amount of funds managed is quite material at this time. All schools have a regular source of income from the allocation of School Operational Assistance funds from the Central Government through the APBD mechanism. The determination of the schools receiving these funds is following the data in the national Basic Education Data Base (DAPODIK), which is incorporated in the Ministry of Education and Culture as of 31 August. The allocation of funds depends on the number of active students in the DAPODIK data and the number of unit costs for each region (Permendikbud No. 6 of 20210. The amount received is quite material, namely for elementary school levels in Jambi Province, it ranges from Rp. 900,000, - Rp.990.000,-. The allocation per student at the junior high school level in Jambi Province is between Rp.1.100.000- and Rp.1.240.000-. The highest allocation per student is in Jambi Province for the West Tanjung Jabung Regency and the lowest for students in Batang Hari Regency, Muaro Jambi Regency, and Jambi City. The unit cost for each area is set in Kepmendikbud No. 16 of 2021. The geographical, social, and economic conditions of each region seem to consider the amount of fund allocation per student.

Schools can use these operational funds to provide education, namely for new student admissions, developing school libraries, financing the implementation of learning and extracurricular activities, conducting assessments and evaluations of the learning process, and administering school activities. These funds can also be used to develop the professionalism of teachers and school staff, pay for recurring operational costs such as electricity, water, or other services, and maintenance of school facilities and infrastructure. Schools can also use it to increase skill competencies, provide multimedia equipment for the learning process, carry out activities to support alumni absorption, and pay honorariums. Operational assistance funds were received directly by all schools in Jambi City. Other types of funds that schools can receive include funds obtained from the school's original income, such as sales of student creations and school businesses, and profit-sharing from the management of the canteen or other school assets. In addition, schools may also receive other grants. Schools that collaborate with other institutions can also receive funds from private companies, banks, and other state companies such as corporate social responsibility funds.

The policy of providing school operational assistance funds is a form of the government's commitment to carry out the mandate of the 1945 Constitution. The allocation of these funds has a counter-productive impact with efforts to increase the participation of the community [18]. Parents who are reluctant to participate but schools are also afraid to accept parental contributions because they are afraid that they will be considered levies. The existence of this fund is also alleged to have resulted in a decrease in the care of parents and the community in the management of education. Parents view that the government seems to have taken over managing education through this fund program [18]. Finally, the school tries to keep up with all changes in financial management policies. The strategy is carried out through comparative studies, working in groups, and using consultants. Schools try to appear homogeneous to get support from their environment [16]. School accountability is also trying to be improved. 
Accountability is important for schools. Apart from being required by government regulations, it can also be used to increase the trust of stakeholders. Stakeholders will not know information related to accountability that has been carried out if transparency is not carried out by schools. Money is usually a sensitive issue in every organization. Therefore, by implementing good financial management transparency, it will not cause suspicion to the school.

\subsection{Good Financial Governance Practices}

The three basic principles of good financial governance, namely participation, accountability, and transparency, are dimensions of implementing good school governance practices. In general, the average score for implementing good financial governance practices is 4.19 , with the composition of good financial governance practices in junior high schools being higher than those in elementary schools. The average value indicates that good financial governance in schools in Jambi City is in a GOOD category. The average value for each dimension is presented in table 1.

Table 1. Table title. Table captions should always be positioned above the tables.

\begin{tabular}{lccc}
\hline GFG Principles & SD & SMP & Average Value \\
\hline Participation & 4,18 & 4,12 & 4,15 \\
Accountability & 4,36 & 4,48 & 4,42 \\
Transparency & 3,73 & 4,25 & 3,39 \\
Average & $\mathbf{4 , 0 9}$ & $\mathbf{4 , 2 9}$ & $\mathbf{4 , 1 9}$ \\
\hline
\end{tabular}

Data Source: Researcher Process

Based on table 1, it is known that the average level of implementation of good financial governance in elementary schools (4.09) is lower than at the junior high school level (4.29). The next researcher describes the implementation of each dimension of good financial governance as follows:

\subsubsection{School Financial Management Participation}

Each dimension of the Good financial governance variable has a different average value of Good financial governance practices. Of the nine questions asked, the participation dimension has an average score of 4.15 (GOOD Category). Based on this table, it is also known that the value of participation practices in elementary schools is higher than participation practices in junior high schools.

Based on the results of FGDs conducted with school principals and strengthened by FGDs conducted with school fund management operators, information was obtained regarding parties participating in school financial management, including parents, school committees, teachers, and employees. The form of parental participation in schools consists of representatives of parents whose activities include attending school budgeting meetings. Parents can write a letter via suggestion boxes, delivered through the school committee, delivered through the teacher, or directly to the principal and present to advise at a school meeting.

Parents can also be active in school activities that cannot be budgeted for through school operational funds-for example, farewell activities, religious celebrations, and national holidays. The management of funds and implementing such activities are directly coordinated 
by a team formed by and from the students' parents. The school is only a facilitator for the provision of places and facilities owned by the school.

The school committee is representative of the parents of students. The school committee is a representative of parents to communicate with the school actively. The school committee plays a crucial role in voicing the aspirations and complaints of parents to the school. One form of school committee participation is to participate in signing the school fund report. This is very clearly regulated in the School Operational Fund Management regulations.

The school's internal stakeholders are teachers and employees. One of the forms of teacher participation in schools is being active in the planning process, participating in using school funds, and preparing reports on sources and uses of school funds. The participation of employees in schools is not much different from that of teachers. In addition, several employees also assist the principal in preparing administration and school fund reports.

Participation can increase motivation for teachers and employees. The active participation of all stakeholders can create potential tensions, disagreements, and differences. However, positive things can arise in developing social skills and behavior and increasing positive actions for the actors involved [19].

\subsubsection{School Financial Management Accountability}

Furthermore, of the six questions related to the accountability dimension, the average value of this dimension is 4.42 (GOOD Category). Based on the composition in Table 1, it can be seen that the accountability dimension has the highest average value when compared to the participation and transparency dimensions. From table 1, it is also known that the average value of accountability practices in junior high schools is 4.48 higher than accountability practices in elementary schools, which is only 4.36 .

The results of the FGD also inform about the accountability of schools. The financial management reports reported by schools in the RKA and school financial reports are reports on BOS funds, other source funds (e.g., DAK), and school original income funds. Regarding BOS funds and other source funds, they are reported separately to the relevant agencies. Reports to the relevant agencies often experience delays, based on the results of the FGD, and it was found that the cause of the delay was the delay in the preparation of the accountability documents. Some schools still manage the school's original income funds, such as those from the school canteen, by compiling reports for the school's internal needs.

Schools carry out accountability as part of governance. Accountability of school funds shows the level of conformity between the plan and use of funds and compliance with applicable regulations. The Ministry of Education and Culture has required schools to use the application management of school budget and activity plans. This, of course, can increase the accountability of school fund management. The logic of school governance refers to the democratic and bureaucratic processes. It is also related to political accountability. Government intervention through various regulations can be seen as governance logic, not business logic from school budgets [20]. This needs to be done to increase accountability in school financial management.

\subsubsection{School Financial Management Transparency}

The dimension of transparency with six indicators obtained an average value of 3.99 (GOOD ENOUGH Category). Furthermore, in junior high schools, the average value of transparency practices is 4.42 , which is higher than transparency practices in elementary 
schools, which is only 3.73. Transparency in the form of disclosure of school financial management information. The results of the FGD also explain the form of transparency practices. There are several forms, including being open by submitting written financial reports to parents. Schools with good financial management and parental participation will be pleased to do this. Written reports are usually not for the overall management of operational aid funds. Written reports are provided for funds originating from direct parental donations for school activities.

Another form of conveying information about the source and use of funds is by utilizing school bulletin boards. Schools that apply this form are by the technical instructions for managing school operational funds. All stakeholders can find out the details of the source and use of school funds. This form simplifies the school transparency process. Some schools also deliver information through outreach to parents. Socialization activities are carried out at the parents' meeting.

Researchers also still find schools that only convey school funds for internal schools, such as teachers and employees. There are still (though not many) principals who do not openly convey school funds to all internal school parties. Only the teachers and staff involved know about it. Access to information for external parties is only obtained by the school committee and reports to the Education Office and the Ministry.

Transparency is important to do to show that schools have implemented good accountability. In addition, to increase parental trust in the school. It is hoped that parents will continue to actively participate in school activities. Parents no longer trust will usually reduce their role in the school.

Furthermore, this study describes descriptive statistics on applying good financial governance practices in elementary and junior high schools. The average score for implementing good financial governance practices in elementary schools is 4.09 . The highest value from applying good financial governance practices comes from answering questions about schools making accountability reports on the use of school funds. The average score for this question is 4.92 . The second highest score came from answers to school fund realization activities made by relevant technical instructions and regulations. The average score for this question is 4 .

Meanwhile, the lowest score for implementing good financial governance practices in elementary schools comes from answers to school activities that report funds from other businesses such as canteens into reports on school funding sources, which is 2,33 . This shows that schools still have not combined the school's original income in the report on school funding sources. This is probably because the amount of funds is not too material compared to the operational funds received from the government. Ideally, all school funding sources, regardless of the amount, should still be included in the school fund report. The accountability for the use of funds can also be known jointly by the stakeholders. Furthermore, the secondlowest score from the application of good financial governance practices in elementary schools came from answers to questions about parents' activities being allowed to ask for clarification on the source and use of school funds to school leaders, which were 3.25.

The average score for implementing good financial governance practices in junior high schools is 4.29. The highest value from implementing good financial governance practices comes from the answers to questions about schools making accountability reports on the use of school funds, which is 4.90 . The second highest score came from the answers to questions about school fund realization activities made by technical instructions and related regulations, which was 4.90. The lowest average score comes from answers to school activities that report funds from other businesses, such as canteens, into reports on school funding sources, which is 
3. The second-lowest average score is related to transparency; namely, the school informs in writing the recapitulation of receipts and funds to parents. Most schools have implemented transparency in the use of funds through information on school bulletin boards only.

From the results of the FGD on the three dimensions above, the researcher also found the informants' views on the characteristics to assess good financial governance. The condition of the school can be stated that good financial governance has been running well if all the core stakeholders of the school actively participate. This is evidenced by the school's stakeholders being actively involved in financial management (parents, committees, teachers, employees). Accountability has been carried out properly as evidenced by the fund management report prepared in accordance with all relevant regulations. Reports are also submitted on time both to the Education Office and via the web to the Ministry of Education and Culture. Transparency in school financial management has been implemented. The report has been submitted through the school notice board to stakeholders. Parents, teachers, and employees can ask the principal directly regarding the use of school funds.

Conditions in schools to declare good financial governance are good enough if there is a condition that only some school stakeholders are actively involved in financial management (committees, teachers, employees). Not all stakeholders, especially parents, are actively involved. Financial management reports have referred to related regulations in the accountability dimension but are still not reported on time. Information disclosure to stakeholders is not carried out through school bulletin boards. Schools submit reports through outreach activities and school meetings to stakeholders.

The condition of the school to declare good financial governance is not good if there is a condition. Participation only involves certain parties in the school in financial management (some teachers and some employees). Not all are actively involved. Financial management reports are often reported late by schools. The transparency dimension is not executed properly. Factors that cause not yet optimal good financial governance in schools from the results of discussions and interviews in the field, among others:

a. Limited human resources. The moratorium on civil servant recruitment in several regions for educators and education staff has limited the number of human resources in schools, especially elementary schools. After the acceptance of civil servants has been done, the amount of receipts is not proportional to those who have retired. So for elementary schools in Jambi City, there are many non-PNS educators and educational staff. Schools, especially schools with a small number of students, also have limitations in accepting noncivil servants. In addition, limitations were also found in terms of the quality of human resources, especially in financial management. Schools are still limited in having human resources who can use information technology-based applications.

b. Limitations of internal auditors and school financial management supervisors. The Jambi City Regional Inspectorate is also responsible for supervising the management of school funds. One problem faced is the limited number of auditor human resources. In addition, the educational background of auditors is multi-disciplinary; not all auditors have an accounting or economic education background.

c. Limited understanding of parents and other stakeholders regarding school financial management. Some schools are still facing obstacles related to the understanding of stakeholders that still need to be optimized regarding accountability and transparency of school financial management. So that the school is sometimes uncomfortable facing excessive stakeholder demands and even out of the rules that have been set.

School supervisors carry out alternative supervision of school financial management.

However, currently, the focus of supervision is dominant in the academic field of the school. 
In the future, school supervisors can be empowered to assist in monitoring and internal school audits. School supervisors are given training and technical guidance in advance regarding regulations and techniques for supervising school financial management. School supervisors can assist the Regional Inspectorate's work. Internal auditors who can carry out the roles of examiners, consultants, and catalysts will improve good governance in government organizations [21].

\subsection{Interaction of Actors to Improve Good Financial Governance in Schools}

Good financial governance in schools will not be achieved if only the principal is active in financial management. Principals need support from all school stakeholders, especially the core stakeholders of school financial management. The research team presents the interaction of the parties/actors related to good financial governance achievement in Figure 1.

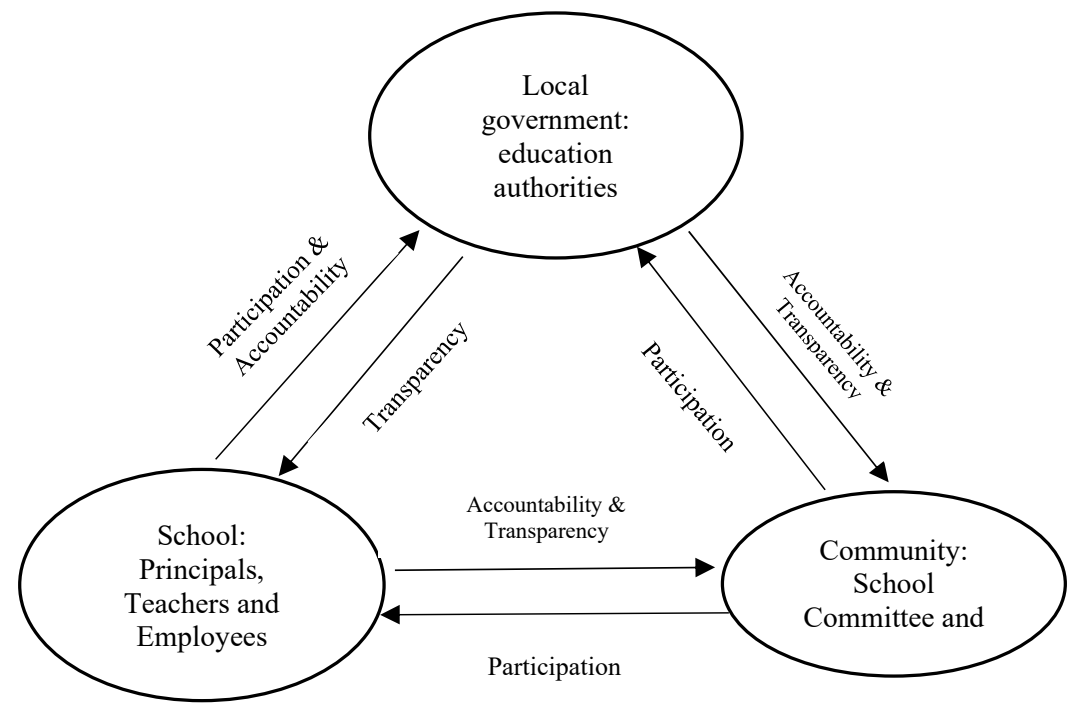

Fig. 1. Ideal Actor Interaction for Improving Good Financial Governance

The Regional Government, in this case, is dominantly given the authority to the Education Office to become a director, facilitator, and motivator so that schools can implement good financial governance. The Education Office always conducts socialization for schools for changes to school financial management regulations. The education office is also active in providing direction and monitoring the management of school funds. The education office interacts with schools in implementing good financial governance by applying the principle of transparency. At least two transparency must be done, namely, transparency regarding the regulations used and transparency on supervision results to schools. Supervision can be carried out directly by the Education Office or by the Regional Inspectorate. Schools must follow up on the results of this supervision to improve financial governance.

The education office also has an obligation to apply the principles of accountability and transparency regarding the financial management of school funds to the community. The community here can be interpreted broadly, including parents, school committees, legislature 
representatives, private companies, and other communities. Funds managed by schools come from the community through the regional budget mechanism. The Education Office coordinates this regional budget. Therefore, the education office must account for the funds managed by all schools by applicable regulations to implement the principle of accountability. Furthermore, transparency in the management of these funds must also be implemented. The public can also know the flow of these funds.

Society has an obligation to participate in the ideal interaction of these actors. The primary role of the community for the dimension of participation in relations with local government is participation in supervising school activities. The community can be a government agency to assess and evaluate the achievement of school financial management results. The community can propose changes in education policy that are needed. The community can participate in providing proposals for school programs and activities in the planning process about schools. Schools also need community participation, especially around schools, to help monitor school activities and even actively monitor students' behavior in the community.

The main actors in managing school finances are the school, namely the principal, teachers, and employees. The principal must be the skipper to determine whether the school's good financial governance is good or not. Schools have an obligation to participate in achieving the vision and mission of the education sector set by the central and regional governments. Schools have an obligation to follow all the rules set and report the use of funds to the local government and the community. In addition, schools also provide access to information related to funding management for both local governments and the community. This is a form of application of the principles of accountability and transparency. The principles of good financial governance are interrelated. Accountability requires the participation of all components and school members. Accountability practices depend on how applicable policies or regulations are institutionalized in the organization. This needs to be done to find the gap between the real, actual and empirical reality domains of the organizational actors involved and the general governance policies (Mutiganda, 2013). The implementation of this account will be known if transparency is implemented. Transparency can increase further participation of stakeholders.

\section{Conclussion}

Schools today are educational institutions and are also given autonomy to manage the funds allocated to schools. Several funds that can be a source of school finance are government assistance funds (Bantah), school operational assistance funds, original school income (PAS), and corporate social responsibility funds from companies/BUMN/BUMD. The flow of school fund management is the same as other government organizations, starting from preparing school budget work plans to financial accountability.

The implementation of good financial governance in Jambi City is already in good condition. When viewed from each dimension, the implementation of participation and accountability has been good, but it is still in the fairly good category for transparency. The main actor in good financial governance is the school-the principal as a manager at the school level. Synergy in interactions between actors will be able to improve and accelerate the achievement of good financial governance.

Local governments must pay attention to the competence of financial managers at the school level. The supervision process must also be improved, one of which is by optimizing the role of school supervisors, not only in the academic field but also in the financial sector. 
Therefore, the technical capabilities of the supervisors also need to be carried out. Dissemination of regulations related to the management of school funds must continue to be carried out. Socialization is for school operational funds and funds from other sources, including original school income. Further researchers can develop this research by using a quantitative approach to examine the actors' interactions or examine the relationship between good financial governance and other variables. A qualitative approach with symbolic interactionism can also be used for further research.

\section{Acknowledgments}

We would like to thank the Rector, the Head of the Institute for Research and Community Service, and the Dean of the Faculty of Economics and Business University of Jambi for their support so that this research can be carried out properly. The research team would also like to thank the Jambi City Education Office and all participants in this study for taking the time and being willing to share information about the focus of this research. We also thank the reviewers and the editor for their comments and recommendations.

\section{References}

[1] I. Indrawati, "Prinsip Good Financial Governance Dalam Pengelolaan Keuangan Negara Dalam Rangka Mewujudkan Clean Governance," Perspektif, vol. 17, no. 3, p. 201, 2012, doi: 10.30742/perspektif.v17i3.109.

[2] Y. Mehralizadeh, H. Sepace, and F. Atashfeshan, "Globalization and decentralization of management: A study of the feasibility of application of school-based management in Iran's secondary schools," Alberta Journal of Educational Research, vol. 52, no. 1. 2006.

[3] G. V. R. K. J. H. Marshal, "Implementation of School-Based Management in Indonesia," Santa Monica, 2012.

[4] OECD, "What Makes schools successful? Resources, Policies and Practices - Volume IV. School Governance, Assessments and Accountability," 2013. [Online]. Available: https://www.oecd.org/pisa/keyfindings/Vol4 Ch4.pdf.

[5] Edb.Gov, "Good Governance: Quality Education. Participatory School Governance," 2010. [Online]. Available: www.edb.gov.hk/attachment/en/schadmin/sbm/corner.../good governance.pdf.

[6] M. Lewis and G. Petterson, "Governance in Education: Raising Performance.," 2009. [Online]. Available: http//: worldbank.org/.../Governance-in-education-master22Dec09-GP.doc.

[7] R. Kasali, Let's Change: Kepemimpinan, Keberanian dan Perubahan. Jakarta: Kompas, 2014.

[8] P. Lanjouw, M. Pradhan, F. Saadah, H. Sayed, and R. Sparrow, "Poverty, Education and Health in Indonesia: Who Benefits from Public Spending? December. Working Paper, World Bank, Washington, DC," Educ. Heal. Expend. Dev. cases Indones. Peru, no. December, pp. 17-48, 2001, [Online]. Available: https://ideas.repec.org/p/wbk/wbrwps/2739.html.

[9] E. Saraswati, "Dampak Efisiensi Belanja Publik Pendidikan terhadap Kesejahteraan (Welfare)," Universitas Indonesia, 2011.

[10] M. C. Jensen and W. H. Meckling, "Theory of the firm: Managerial behavior, agency 
costs and ownership structure," J. financ. econ., vol. 3, no. 4, 1976, doi: 10.1016/0304405X(76)90026-X.

[11] Halim dan Abdullah, "Hubungan Dan Masalah Keagenan Di Pemerintah Daerah: Sebuah Peluang Penelitian Anggaran dan Akuntansi," J. Akunt. Pemerintah., vol. 2, no. 1, pp. 53-64, 2006.

[12] Mulyasa, Manajemen Berbasis Sekolah: Konsep, Strategi dan Implementasi. Bandung: PT Remaja Rosdakarya, 2012.

[13] A. Wibowo, Akuntabilitas Pendidikan: Upaya Meningkatkan Mutu dan Citra Sekolah. Yogyakarta: Pustaka Pelajar, 2013.

[14] Sugiyono, Metode Penelitian Kuantitatif, Kualitatif dan R\& D. Bandung: Alfabeta, 2017.

[15] Jogiyanto, Metodologi: Penelitian Bisnis. Yogyakarta: BPFE UGM, 2010.

[16] S. Rahayu, "Institutionalization Process of SOAFunds Budgeting at Basic Education Institutions in Indonesia," Res. J. Financ. Account. www.iiste.org ISSN, vol. 7, no. 4, pp. 104-111, 2016, [Online]. Available: www.iiste.org.

[17] B. Bungin, Post-Qualitative: Socail Research Methods (Kuantitaif-Kualitatif-Mix Method). Jakarta: Penerbit Kencana, 2020.

[18] S. Budiyati, N., and Toyamah, "Dampak Program BOS terhadap Partisipasi Masyarakat dalam Pendanaan Pendidikan," www.smeru.or.id, 2006.

[19] A. R. Bryer, "Participation in budgeting: A critical anthropological approach," Accounting, Organ. Soc., vol. 39, no. 7, pp. 511-530, 2014, doi: 10.1016/j.aos.2014.07.001.

[20] M. Ezzamel, K. Robson, and P. Stapleton, "The logics of budgeting: Theorization and practice variation in the educational field," Accounting, Organ. Soc., vol. 37, no. 5, pp. 281-303, 2012, doi: 10.1016/j.aos.2012.03.005.

[21] S. Rahayu, Yudi, and Rahayu, "Internal auditors role indicators and their support of good governance," Cogent Bus. Manag., vol. 7, no. 1, 2020, doi: $10.1080 / 23311975.2020 .1751020$. 